\title{
EVALUATION OF THE FLORISTIC COMPOSITION AND SOIL PROPERTIES OF GRASSLANDS IN THE MOHELNO SERPENTINE STEPPE 20 YEARS SINCE THE REINTRODUCTION OF SHEEP GRAZING
}

\author{
Marie Mrázková-Štýbnarová1, Pavel Veselý², Jaroslav Čáp³, \\ Karel Fiala ${ }^{1}$, Aleš Dufek ${ }^{1}$

\begin{abstract}
${ }^{1}$ Agrovýzkum Rapotín s. r. o., Výzkumníků 267, 788 13, Vikýřovice, Czech Republic
${ }^{2}$ Department of Animal Nutrition and Forage Production, Faculty of AgriSciences, Mendel University in Brno, Zemědělská 1, 61300 Brno, Czech Republic

${ }^{3}$ Czech Botanical Society, Benátská 433/2, 12801 Praha 2 - Nové Město, Czech Republic
\end{abstract}

Link to this article: https://doi.org/10.11118/actaun.2021.001

Received: 20. 3. 2020, Accepted: 3. 8. 2020

To cite this article: MRÁZKOVÁ-ŠTÝBNAROVÁ MARIE, VESELÝ PAVEL, ČÁP JAROSLAV, FIALA KAREL, DUFEK ALEŠ. 2021. Evaluation of the Floristic Composition and Soil Properties of Grasslands in the Mohelno Serpentine Steppe 20 Years Since the Reintroduction of Sheep Grazing. Acta Universitatis Agriculturae et Silviculturae Mendelianae Brunensis, 69(1): 11-20.

\begin{abstract}
In the paper there is evaluated floristic composition and soil characteristics of grasslands in the Mohelno Serpentine Steppe, where the sheep grazing was renewed after ca 60 years in 1997. Soil samples were collected in spring 2016 from 9 permanent plots MHS 1-9 in the same date as the phytocoenological relevés were conducted. In the soil there was determined the soil acidity and the content of macro- and micronutrients. Data were evaluated using RDA (redundance analysis). It was found the higher dominance of species such as: Plantago lanceolata L., Festuca pseudovina Hack. ex Wiesb., Achillea collina Heimerl, Cerastium arvense L. and Centaurea scabiosa L. by higher content of basic macronutrients (N, P, K) in the soil. There is was apparent tendency for the decrease in the species diversity connected with increasing soil nutrient content.
\end{abstract}

Keywords: renewed grazing, small ruminants, species diversity, soil characteristics, nature conservation

\section{INTRODUCTION}

In our country, grazing has always been the most natural and cheapest way to manage permanent grassland (Komberec et al., 1993; Fiala and Gaisler, 1999). The importance of grazing is gaining importance especially in less favored areas, called areas of natural constraints (ANC), where ruminant breeding is difficult to replace by other forms of agrarian activity. In these areas, permanent grassland is not only a potential producer of forage, but also contributes significantly to the creation of a cultural landscape and the conservation of its biodiversity (Merunková and Chytrý, 2012;
Hellström et al., 2003). As documented by a number of authors (Dullinger et al., 2003; Isselstein et al., 2005; Prévosto et al., 2011), retreating from seminatural grassland poses the greatest risk to species diversity. Therefore, grazing is often used in protected areas of the Czech Republic, the number and area of which have increased significantly in recent years. As part of the management that has been carried out in these localities, grazing has recorded a direct renaissance (Veselý, 2000; Žáková et al., 2004; Hejcman et al., 2006; Hofhanzlová, 2006; Mládek et al., 2006; Pavlů et al., 2007; Mládek, 2008; Brabec et al., 2011). 
Especially in the rugged terrain of protected areas, which are typically characterized by lower nutritional value and uneven surface distribution of above-ground biomass, grazing of small ruminants has traditionally been used for grassland maintenance (Spatz et al., 1999; Lombardi, 2005). Grazing on these sites has a number of specifics. However, their respect should never lead to the requirements of grazing animals not being sufficiently taken into account. Therefore, it is necessary to know the food preferences of individual animal species and subsequently to use them in favor of grazing area (Veselý, 2014).

The aim of this work was to evaluate the state of floristic composition and soil parameters of grass communities in the Mohelno Serpentine Steppe National Nature Reserve 20 years after the reintroduction of sheep grazing.

\section{MATERIALS AND METHODS}

\section{Site Description}

The study of floristic composition and soil conditions was performed in the Mohelno Serpentine Steppe National Nature Reserve. The steppe is situated in the foothills of the Bohemian-Moravian Highlands, on the so-called Náměšt Plateau, in the cut canyon of the Jihlava River (which is 130-150 m below Mohelno) mostly on steep, longitudinally divided and southexposed rocky slopes of the valley on the left bank of the river. The area also partially occupies gentle slopes and a plateau above the valley. Specific microclimatic conditions (predominant southern exposures and specific geological background) determine the occurrence of relict plant communities and the exceptional occurrence of many species of organisms (Veselý, 2002).

Data about monthly mean temperatures $\left({ }^{\circ} \mathrm{C}\right)$ and sum of precipitations (mm) for April-October in 2016 are summarized in Fig. 1.

\section{Grazing Management}

Renewed sheep grazing was carried out in 19972019, approximately 60 years after the steppe was last farmed, either by grazing or mowing (Veselý, 2002). In 1997-2003, free grazing with an electric fence was performed on the steppe, in 2004-2010 guarded grazing with the aid of a shepherd dog was carried out, and since 2011, free grazing with the help of an electric fence was applied again (Veselý and Havlíček, 2011). In the period 1997-2003 the grazing area ranged from 4.2 to 8.9 ha and it was grazed by 14-59 sheep. In the period 2004-2010, the grazing area was not quantified and the number of animals in the herd ranged from 82 to 293. In the period 2010-2019, only defined steppe segments were grazed with 176 (136 ewes + 40 lambs) sheep.

\section{Evaluation of Floristic Composition}

Based on the overall floristic evaluation, the vegetation present in the grazing area can be characterized as T3.3 narrow-leaved dry grasslands (Chytrý et al., 2010). The floristic composition of grassland communities was evaluated in detail in the spring period of 2016 using the method of phytosociological relevés (Moravec et al., 1994) of nine defined permanent plots MHS 1-9 (Fig. 2); the area of one plot was $4 \mathrm{~m} \times 4 \mathrm{~m}$. The coverage of the species population in the evaluated cenoses was determined by an estimation method using the

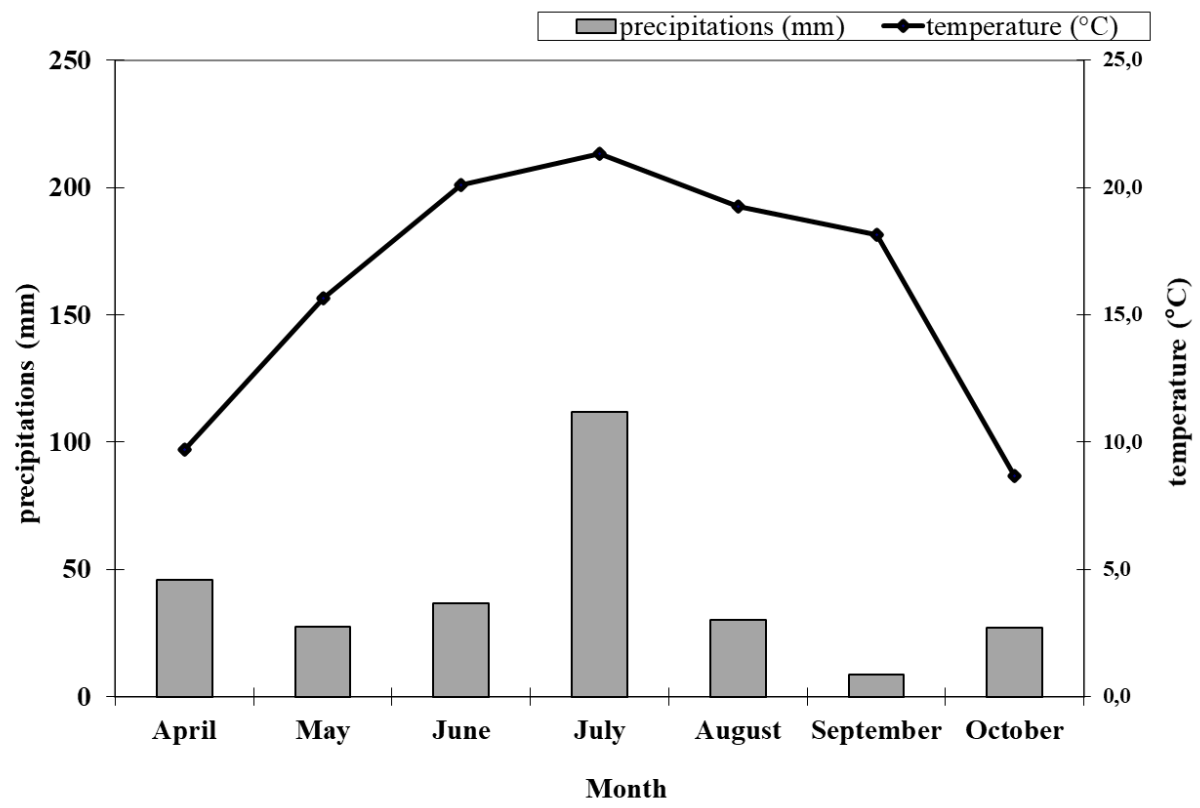

1: Monthly mean temperatures $\left({ }^{\circ} \mathrm{C}\right)$ and sum of precipitations $(\mathrm{mm})$ for April-October in 2016 Quelle: Whether station Brno-Soběšice 
I: Domin-Hadač scale (Moravec et al., 1994).

\begin{tabular}{cc}
\hline Cover class & Range of cover \\
\hline+ & single individual \\
1 & sporadic or few individuals \\
2 & $<1 \%$ \\
3 & $1-4 \%$ \\
4 & $5-10 \%$ \\
5 & $11-25 \%$ \\
6 & $26-33 \%$ \\
7 & $34-50 \%$ \\
8 & $51-75 \%$ \\
9 & $76-90 \%$ \\
10 & $91-100 \%$ \\
\hline
\end{tabular}

Domin-Hadač scale (Moravec et al., 1994), which is presented in Tab. I.

There are several principles for performing exact phytosociological relevés of grassland. The primary principle is that the placement of the plot, the choice of its location, must be done so that the area to be scanned lies in the same stand type (association). It must not be located at the interface of two stand types (usually at the interface of different habitat conditions). If it is necessary to cover a larger area of vegetation, in which several stands are represented, it is necessary to prepare phytosociological relevé (s) for each stand type (association) separately. The selected plot for the phytosociological relevé should represent a significantly larger surrounding area with approximately the same floristic composition.

\section{Evaluation of Soil Parameters}

The soil was classified as rendzina on the basis of a preliminary assessment (Němeček et al., 2011) as well as previous literary data (Pelíšek, 1939; 1948), according to the author as "magnesium rendzina". It is a grained light soil, weakly acidic, with a very high (pseudo) total nitrogen content (Fiala and Krhovjáková, 2009).

Soil samples for the determination of basic chemical parameters were taken from nine permanent plots MHS 1-9 (Fig. 2) in 2016 at the same spring time as the phytosociological relevés were performed. Samples were taken with a soil drill from a depth of $2-15 \mathrm{~cm}$ after preliminary removal of the surface sod. Each soil sample was obtained from three punctures with a soil drill and homogenization of the soil taken. The dried soil samples were transferred to fine earth $(<2 \mathrm{~mm})$ and the soil exchange reaction $\left(\mathrm{pH} / \mathrm{CaCl}_{2}\right)$ was determined. The samples were further analyzed for the content of plant-available nutrients $\mathrm{P}, \mathrm{K}$, $\mathrm{Mg}$ and $\mathrm{Ca}$ in the Mehlich-3 (M-3) leachate and for the pseudototal nitrogen content according to Kjeldahl (Zbíral et al., 2010 and Zbíral et al., 2004 respectively). Particular emphasis was put on the analysis of selected risk elements (Co, Cr, Cu, $\mathrm{Mn}$ and $\mathrm{Ni}$ ), where their pseudototal content was determined by the influence of the aqua regia on the soil matrix under increased pressure and temperature in the microwave decomposition system (Zbíral et al., 2011). The contents of Co, Cr and Ni were analyzed by the ETA-AAS method in the $1 \mathrm{M}$ $\mathrm{NH}_{4} \mathrm{NO}_{3}$ extract, the other metals in the aqua regia and M-3 extracts by flame modification (FAAS). The $\mathrm{P}$ content was determined spectrophotometrically. All analyzes were performed in the accredited laboratory of Agrovýzkum Rapotín s.r.o.

\section{Statistical Analysis}

RDA (redundancy analysis) in CANOCO for Windows 4.5 was used for detailed analysis of phytosociological data (ter Braak and Šmilauer, 2002). There were 16 soil indicators behind the explanatory variables. Domin-Hadač scale coverage values for 58 species in 9 relevés were input as dependent variables related to species data. Centering of species was used in the analysis. The statistical significance of canonical axes was determined by the Monte Carlo permutation test. The creation and modification of the projection diagrams was based on the results of the analyzes performed by CanoDraw for Windows 4.14.

\section{RESULTS}

The total number of vascular plant species in individual permanent plots ranged from 10 to 26, while a higher total number of vascular species was found in plots No. 3 and 4, the lowest in plot No. 7. The occurrence of woody plants was not recorded.

Based on redundancy analysis, 3 ordination plots were created. The first ordination plot (Fig. 3) shows the relationships between all monitored species and all soil indicators. Together, the first and second axes shown in the diagram account for $53.9 \%$ of the total variability, with the first axis accounting for $34.8 \%$ and the second axis 19.1\%. However, the significance test for this operation was insignificant $(\mathrm{p}=1)$ due to too many explanatory variables (soil indicators).

The relevant RDA ordination plot shows the first two canonical axes (center vertical and horizontal), the guideline for increasing the coverage of the species, and the guideline for increasing the values of each soil indicator. The diagram shows a tendency that some species of higher dominance have responded to the higher content of macroelements N, P, K in the soil, for example: Plantago lanceolata L., Festuca pseudovina Hack. ex Wiesb., Achillea collina Heimerl, Cerastium arvense L. and Centaurea scabiosa L. With a higher content of zinc in the soil, the species were higher in the stands: Carduus acanthoides L., Hieracium echioides Lumn., Avenula pubescens (Huds.) Dum. and Alopecurus pratensis L. Furthermore, it can be seen from Fig. 3 which species were more dominant in the stands with higher manganese content in the soil - for example 


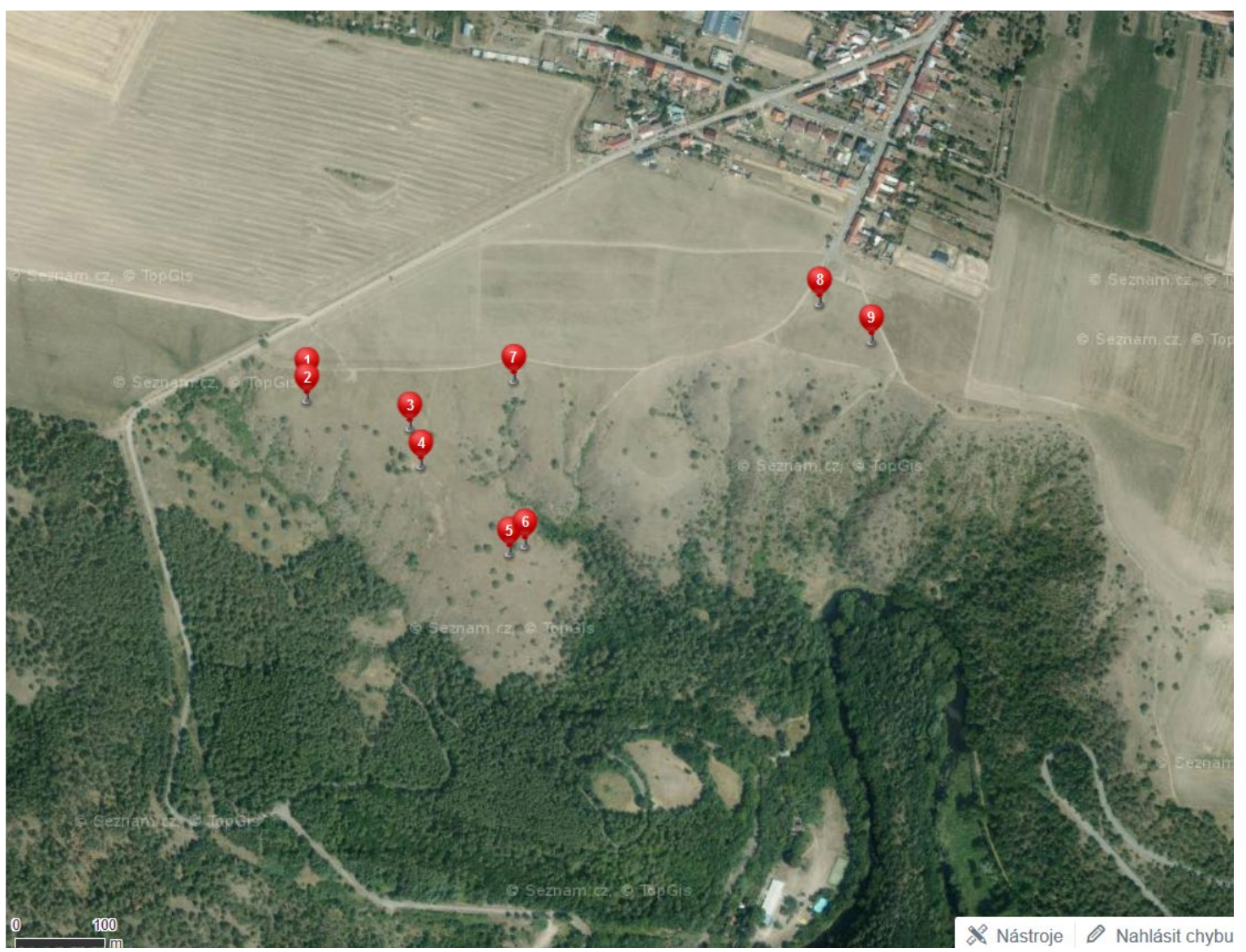

2: GPS localization of permanent plots in the Mohelno Serpentine Steppe

Source: Mapy.cz

Legend:

Plot No. 1 (MHS 1) ... N 4906.553’ E $016^{\circ} 10.599^{\prime}$

Plot No. 2 (MHS 2) ... N 4906.543’ E 016¹0.599

Plot No. 3 (MHS 3) ... N 49 $06.526^{\prime}$ E $016^{\circ} 10.695^{\prime}$

Plot No. 4 (MHS 4) ... N 4906.503' E 016²10.705

Plot No. 5 (MHS 5) ... N 4906.450’ E 016¹0.787

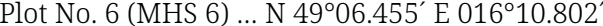

Plot No. 7 (MHS 7) ... N 4906.555' E $016^{\circ} 10.791^{\prime}$

Plot No. 8 (MHS 8) ... N 49 $9^{\circ} 06.602^{\prime}$ E $016^{\circ} 11.076$

Plot No. 9 (MHS 9) ... N 4906.605' E 016²11.101'

Galium verum L. Our results show that species that prefer a lower supply of nutrients in the soil are, for example, Carex caryophyllea Latourr., Carex praecox Schreb., Dianthus carthusianorum L., Dorycnium germanicum (Gremli) Rikli, Potentilla puberula Krašan, Silene otites (L.) Wib., Trifolium campestre Schreber or Veronica prostrata L.

Within the RDA, each soil indicator was evaluated separately in the context of the others. The only conclusive indicator associated with increased variability in the composition of evaluated stands was the content of phosphorus in the soil at the level of $22 \%$ of the total variability integrating with all monitored environmental factors $(F=2.04$; $p=0.038$ ). The ordination plot for the relationship between phosphorus and botanical composition is shown in Fig. 4.
The relationships between soil indicators and number of species (species richness) are represented by the centroid protection diagram in Fig. 5, which shows the number of species in nine relevés, and how these relevés are deployed in the ordinance area relative to soil quality indicators. The number of species in the relevé corresponds to the size of the circle, and these are specified by a number. It is clear from Fig. 5 that the highest number of species in stands (26 species in total) was found in permanent plots, which at the same time showed the lowest content of evaluated nutrients in the soil. Thus, there is an apparent trend towards decreasing grassland species diversity associated with a higher supply of nutrients in the soil. 


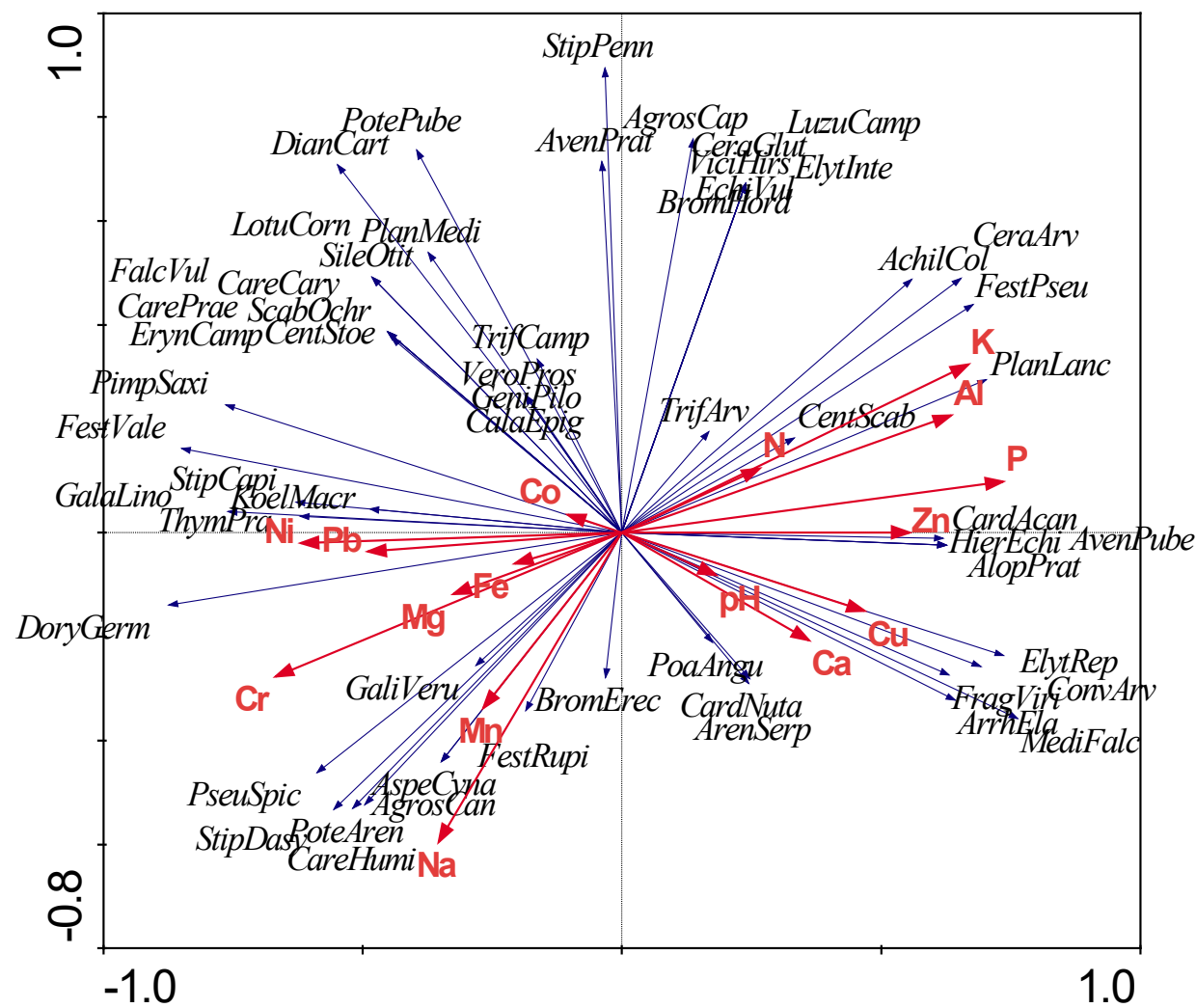

3: RDA ordination plot expressing relationships between soil indicators and species composition Legend:

AchilCol = Achillea collina Heimerl; AgrosCan = Agrostis canina L.; AgrosCap = Agrostis capillaris L.; AlopPrat $=$ Alopecurus pratensis L.; ArenSerp $=$ Arenaria serpyllifolia L.; ArrhEla $=$ Arrhenatherum elatius (L.) J. Presl et C. Presl; AspeCyna = Asperula cynanchica L.; AvenPrat = Avenula pratensis (L.) Dumort; AvenPube = Avenula pubescens (Huds.) Dum.; BromErec = Bromus erectus Huds.; BromHord = Bromus hordeaceus L.; CalaEpig = Calamagrostis epigejos (L.) Roth; CardAcan = Carduus acanthoides L.; CardNuta = Carduus nutans L.; CareCary = Carex caryophyllea Latourr.; CareHumi = Carex humilis Leyss.; CarePrae = Carex praecox Schreb.; CentScab = Centaurea scabiosa L.; CentStoe = Centaurea stoebe L.; CeraArv = Cerastium arvense L.; CeraGlut $=$ Cerastium glutinosum Fr.; ConvArv = Convolvulus arvensis L.; DianCart = Dianthus carthusianorum L.; DoryGerm = Dorycnium germanicum (Gremli) Rikli; EchiVul = Echium vulgare L.; ElytInte = Elytrigia intermedia (Host) Nevski; ElytRep = Elytrigia repens (L.) Nevski; ErynCamp = Eryngium campestre L.; FalcVul = Falcaria vulgaris Bernh.; FestPseu = Festuca pseudovina Hack. ex Wiesb.; FestRupi = Festuca rupicola Heuff.; FestVale = Festuca valesiaca Schleich. ex Gaudin; FragViri $=$ Fragaria viridis Weston; GalaLino = Galatella linosyris (L.) Rchb. f.; GaliVeru = Galium verum L.; GeniPilo = Genista pilosa L.; HierEchi = Hieracium echioides Lumn.; KoelMacr = Koeleria macrantha (Ledeb.) Schult.; LotuCorn = Lotus corniculatus L.; LuzuCamp = Luzula campestris (L.) DC.; MediFalc $=$ Medicago falcata L.; PimpSaxi = Pimpinela saxifraga L.; PlanLanc = Plantago lanceolata L.; PlanMedi = Plantago media L.; PoaAngu = Poa angustifolia L.; PoteAren = Potentilla arenaria Borkh.; PotePube = Potentilla puberula Krašan; PseuSpic = Pseudolysimachion spicatum (L.) Opiz; ScabOchr = Scabiosa ochroleuca L.; SileOtit = Silene otites (L.) Wib.; StipCapi = Stipa capillata L.; StipDasy = Stipa dasyphylla (Lindem.) Trautv.; StipPenn = Stipa pennata L.; ThymPra = Thymus praecox Opiz; TrifArv = Trifolium arvense L.; TrifCamp = Trifolium campestre Schreber; VeroPros = Veronica prostrata L.; ViciHirs = Vicia hirsuta (L.) S. F. Gray

\section{DISCUSSION}

After the restoration of grazing in a locality where grassland in the past (before World War II) was demonstrably used as meadows and pastures (Veselý, 2002), we can expect positive changes in terms of floristic composition and species diversity in the future. Grazing leads to a decrease in the proportion of old plants and illumination of places originally densely overgrown with unwanted dominants. In addition, grazing results in the return of nutrients to the soil, which also changes the chemical soil properties. Due to the load of sheep grazing, exposed areas necessary for germination of a number of plant species are created in places (Krahulec et al., 1996), incl. species protected by law.

The spontaneous succession of stands after a change in management is a long-term process typical and unique for each individual locality and time period (Tasser and Tappeiner, 2002; Kahmen 


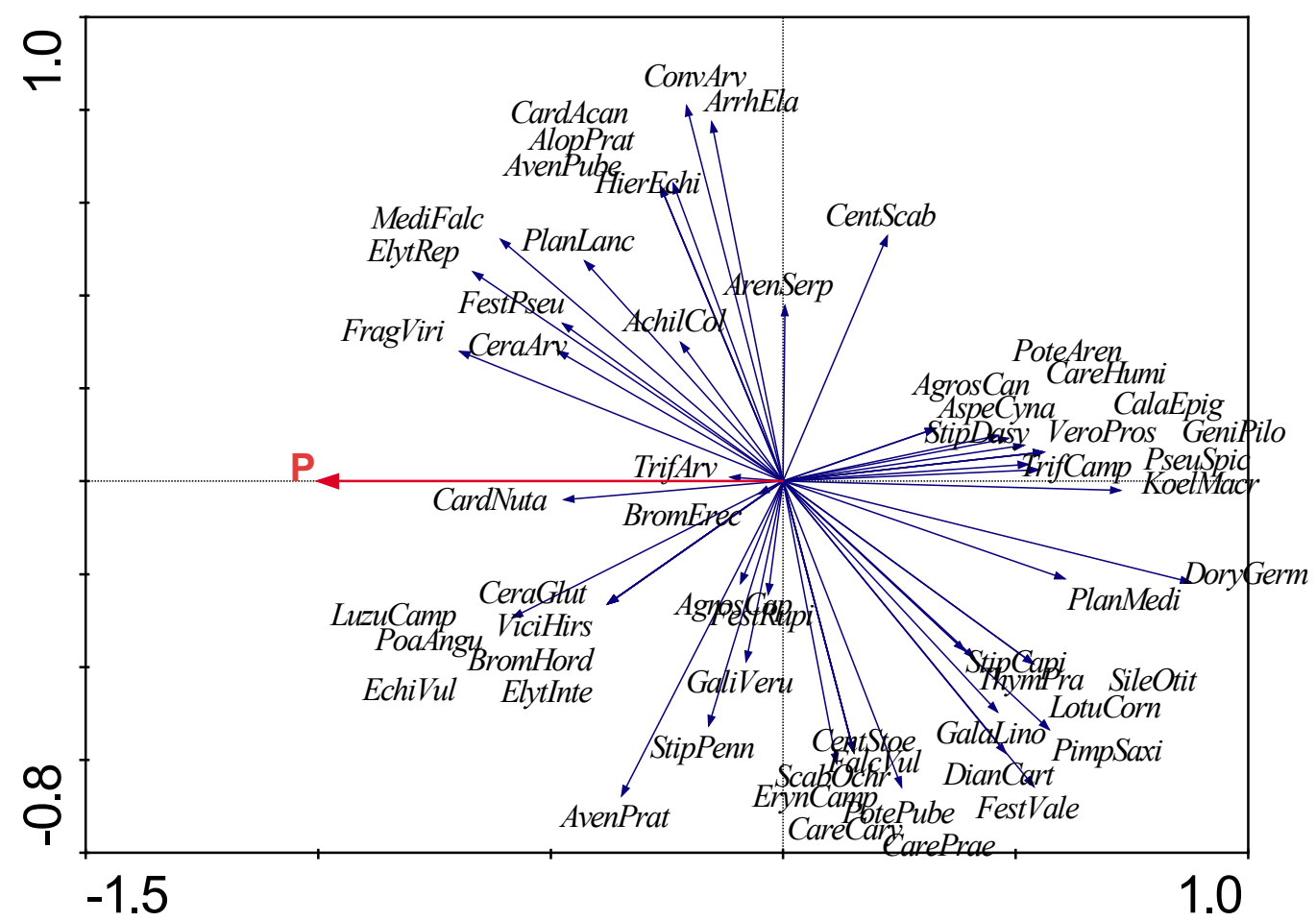

4: RDA ordination plot expressing relationships between soil phosphorus and species composition LEGEND: see Fig. 2

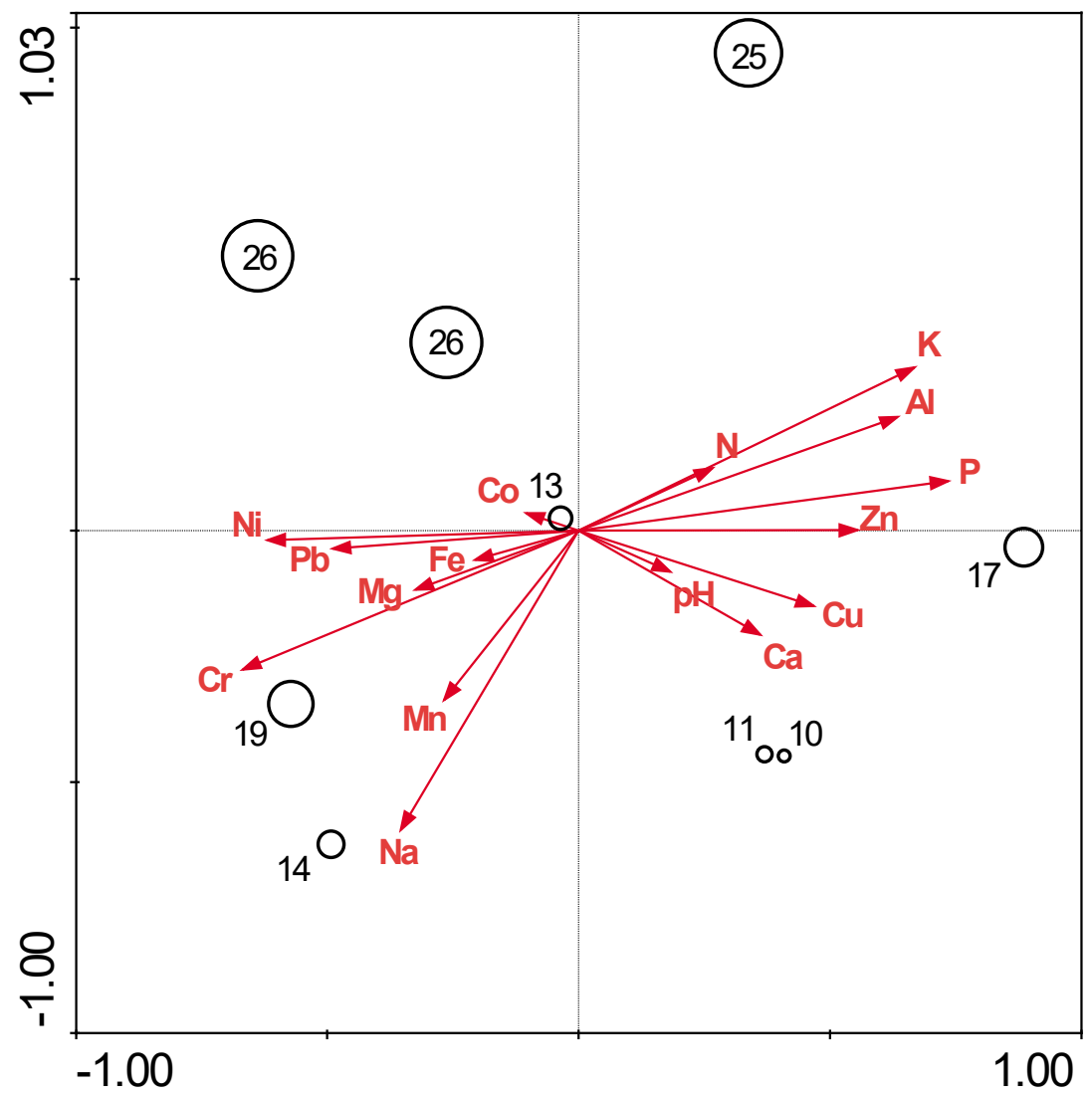

5: RDA ordination plot expressing relationships between soil parameters and number of species on nine permanent plots. The number and size of the ring indicate the number of species per plot. 
and Poschlod, 2004). According to Hejcman et al. (2002), only about 40 years after the introduction of grazing as a new management does a typical grazing stand develop. However, some positive results can also be found in the shorter term, as some recent studies have shown. For example, Veselý and Řepka (2005) dealt with experimental sheep grazing in the Mohelno Serpentine Steppe. Their study showed that five years after the restoration of grazing, species diversity increased on the monitored plots, which were mainly represented by species represented in the stand scattered, very scattered, rarely, or quite rarely.

In the Czech Republic, the inclusion of sheep grazing in the maintenance management of the protected area was also applied in the Protected Landscape Area Beskydy (Piro and Wolfová, 2008) or in the Protected Landscape Area Bílé Karpaty, where the project VaV/620/11/03 "Grazing as a tool for maintenance of permanent grassland in Protected Landscape Area” (Mládek, 2008).

In the years 2011-2016, research was also carried out in the Louny Central Highlands focused on the active protection of internationally important steppe communities (LIFE + project). The main objective of the project was to ensure sustainable management of steppe habitats using traditional farming methods, especially sheep and goat grazing, and its coordinating beneficiary was the Agency for Nature Conservation and Landscape Protection of the Czech Republic (Korbelová and Kopecký, 2016).

The KRNAP Administration also solved a project partially funded by the European Commission: "LIFE CORCONTICA - Living for the Krkonoše Meadows" (2012-2018). Even in this protected area, targeted care for mountain meadows and animal grazing should help to preserve biodiversity, ecological stability and landscape-forming functions of semi-natural grasslands.

Regarding current research in the Protected Landscape Area of Jeseníky (Praděd Natural Nature Reserve), the introduction of renewed cattle grazing around the Švýcárna tourist lodge not only represents a symbolic return to traditional farming, but it is primarily a tool to increase plant and invertebrate species diversity. The solution of this issue requires mutual cooperation of experts from various areas and evaluation of grazing effects from several points of view, incl. assessment of potential risks (Štýbnarová and Mičová, 2014).

An example of the positive effect of grazing on world-wide conservation habitats is Lord (1990), who, on the basis of phytosociological assessments conducted in New Zealand, concluded that grazing is essential for the conservation of native species. This observation was also reflected in the development of biodiversity in mountain pastures, as observed by Kasperczyk and Sczewczyk (1999). Gutser and Kuhn (1998), Partzsch (2000) or
Drozdz (2001) also emphasize the importance of grazing for the maintenance of valuable grassland communities.

Serpentine plant communities are often reported to have soil metal toxicity, particularly increased levels of $\mathrm{Co}, \mathrm{Cr}$ and $\mathrm{Ni}$, significantly affecting their biodiversity. For example, D'Amico et al. (2014) documented that non-endemic species suffer from so-called "serpentine syndrome" on serpentine habitats due to high $\mathrm{Ni}$ and $\mathrm{Mg}$ content, low nutrient content and low $\mathrm{Ca} / \mathrm{Mg}$ ratio in soil. When studying serpentine communities in the Inner Alpine Region of Italy, they concluded that the occurrence of some plant species on serpents is most often associated with a higher occurrence of $\mathrm{Ni}$, while their exclusion from plant communities due to the high $\mathrm{Mg}$ content is rare. At the same time, they concluded that endemic species are generally adapted to both factors. However, this statement is contradicted by many authors. For example, Chiarucci and Dominicis (1995) reported that the composition of grass serpentine communities was more determined by nutritional soil characteristics than the aforementioned soil metal toxicity. Alekseeva-Popova and Drozdova (1994) mentioned that the effects of the factors discussed interacted with each other. The main factors influencing the occurrence of some species on serpentines were low Ca concentration, lower $\mathrm{Ca} / \mathrm{Mg}$ ratio and higher $\mathrm{Ni}$ level in serpentine soils.

Based on our study, it was confirmed that the number of species was higher in the case of permanent plots that showed lower concentrations of monitored nutrients in the soil. Vozár and Jančovič (2004) found that at a higher level of nitrogen in soil in particular, the total number of species in grassland can be reduced by $50-60 \%$. Also, ten years of research by Britaňák et al. (2009) supported the hypothesis of plant species loss by man-induced soil eutrophication. Therefore, environmentally-oriented grassland management practices should take into account excessive nitrogen inputs to the soil. In addition, it is necessary to take into account the reduction in phosphorus doses, as evidenced by the findings of Hejcman et al. (2007). Significant influence of phosphorus on vegetation structure (especially development of legumes) and species diversity was also mentioned by other authors (Wassen et al., 2005; Bullock and Pywell, 2005).

As Veselý and Havlíček (2011) referred, grazing animals in protected areas should never be an end in itself. It should always meet the objectives set by the management plan for a given habitat, within a given time frame. These should be implemented efficiently and should always be realized in accordance with the requirements of the management plan for the area. 


\section{CONCLUSION}

Based on our study, it can be stated that species such as: Plantago lanceolata L., Festuca pseudovina Hack. ex Wiesb., Achillea collina Heimerl, Cerastium arvense L. and Centaurea scabiosa L. reacted with their higher dominance to higher content of macroelements N, P, K in the soil. The results showed a trend towards decreasing species diversity of grassland communities associated with a higher supply of nutrients in the soil.

The positive effect of grazing can also be found in the fact that grazing prevents the spread of tall grass species, which would suppress less competitive species, which would ultimately lead to a reduction in species diversity.

Acknowledgements

The work was supported by the Ministry of Agriculture of the Czech Republic, institutional support MZE-RO1218.

\section{REFERENCES}

ALEKSEEVA-POPOVA, N. V. and DROZDOVA, I. V. 1994. The features of the mineral plant and soil composition of the ultrabasic rocks in the Ust-Belskiy massif (the middle reaches of the Anadyr River). I. The soils. Botanicheskii Zhurnal, 79(7): 75-85.

BRABEC, J., BUCHAROVÁ, A. and ŠTEFÁNEK, M. 2011. Vliv obhospodařování na životní cyklus hořečku mnohotvarého českého (Gentianella praecox subsp. bohemica). Př́roda, 31: 85-109.

BRITAŇÁK, N., ILAVSKÁ, I. and HANZES, L'. 2009. An impact of mineral fertilization on the stability of seminatural grassland at excessive or deficient rainfall. Agriculture (Polinohospodárstvo), 55(3): 139-146.

BULLOCK, J. M. and PYWELL, R. F. 2005. Rhinanthus: a tool for restoring diverse grassland? Folia Geobotanica, 40: 273-288.

CHIARUCCI, A. and DOMINICIS, V. DE. 1995. Effects of pine plantations on ultramafic vegetation of central Italy. Israel-Journal-of-Plant-Sciences, 43(1): 7-20.

CHYTRÝ, M., KUČERA, T., KOČÍ, M., GRULICH, V. and LUSTYK, P. (Eds.). 2010. Katalog biotopů České republiky. Praha: Agentura ochrany př́rody a krajiny ČR.

D'AMICO, M. E., BONIFACIO, E. and ZANINI, E. 2014. Relationships between serpentine soils and vegetation in a xeric inner-Alpine environment. Plant and Soil, 376(1/2): 111-128.

DROZDZ, A. 2001. O potrzebie wprowadzenia zasad zrownowazonej produkcji zwierzecej w gorach. Roczniki Naukowe Zootechniki, 11: 55-63.

DULLINGER, S., DIRNBÖCK, T., GREIMLER, J. and GRABHERR, G. 2003. A resampling approach for evaluating effects of pasture abandonment on subalpine plant species diversity. Journal of Vegetation Science, 14(2): 243-252.

FIALA, J. and GAISLER, J. 1999. Obhospodařování travních porostů pícninářsky nevyužívaných. Metodiky pro zemědělskou praxi - 5. Praha: Ústav zemědělských a potravinářských informací.

FIALA, K. and KRHOVJÁKOVÁ, J. 2009. Metodické postupy a zásady vyhodnocování chemických parametrů půd pod trvalými travními porosty. Uplatněná certifikovaná metodika. Rapotín: Agrovýzkum Rapotín s.r.o.

GUTSER, D. and KUHN, J. 1998. Schaf- und Ziegenbeweidung ehemaliger Mahder (Buckelwiesen bei Mittenwald): Auswirkungen auf Vegetation und Flora, Empfehlungen zum Beweidungsmodus. Zeitschrift für Ökologie und Naturschutz, 7(2): 85-97.

HEJCMAN, M., KLAUDISOVÁ, M., SCHELLBERG, J. and HONSOVÁ, D. 2007. The Rengen Grassland Experiment: Plant species composition after 64 years of fertilizer application. Agriculture, Ecosystems and Environment, 122(2): 259-266.

HEJCMAN, M., PAVLŮ, V., HEJCMANOVÁ, P., GAISLER, J., HAKL, J. and RAUCH, O. 2006. Farmer decision making and its effect on the subalpine grassland succession in the Giant Mts., Czech Republic. Acta Societatis Botanicorum Polonia, 75(2): 165-174.

HEJCMAN, M., PAVLŮ, V. and KRAHULEC, F. 2002. Pastva hospodářských zvířat a její využití v ochranářské praxi. Zprávy Čes. Bot. Společ., 37: 203-216.

HELLSTRÖM, K., HUHTA, A. P., RAUTIO, P., TUOMI, J., OKSANEN, J. and LAINE, K. 2003. Use of sheep grazing in the restoration of semi-natural meadows in northern Finland. Applied Vegetation Science, 6(1): 45-52.

HOFHANZLOVÁ, E. 2006. Hořec panonský - alpský rodák symbolem Šumavy. Živa, 4: 155-157.

ISSELSTEIN, J., JEANGROS, B. and PAVLŮ, V. 2005. Agronomic aspects of biodiversity targeted management of temperate grasslands in Europe - A review. Agronomy Research, 3(2): 139-151. 
KAHMEN, S. and POSCHLOD, P. 2004. Plant functional trait responses to grassland succession over 25 years. Journal of Vegetation Science, 15(1): 21-32.

KASPERCZYK, M. and SCZEWCZYK, W. 1999. Sklad florystyczny runi gorskich uzytkow zielonych po zaprzestaniu uzytkowania. Folia Universitatis Agriculturae Stetinensis. Agricultura, 75: 163-165.

KOMBEREC, S., HOMOLA, V. and KNOBOVÁ, A. 1993. Hospodaření zemědělců v chráněných územích. $1^{\text {st }}$ Edition. Praha: Institut výchovy a vzdělávání ministerstva zemědělství ČR, $30 \mathrm{~s}$.

KORBELOVÁ, J. and KOPECKÝ, V. 2016. Projekt Life+. Stepi Lounského středohoři. AOPK ČR.

KRAHULEC, F., BLAŽKOVÁ, D., BALÁTOVÁ-TULÁČKOVÁ, E., ŠTURSA, J., PECHÁČKOVÁ, S. and FABŠČIČOVÁ, M. 1996. Louky Krkonoš: rostlinná společenstva a jejich dynamika. Opera Corcontica, 33: 3-250.

LOMBARDI, G. 2005. Optimum management and quality pastures for sheep and goat in mountain areas. In: ALCAIDE, M. E., SALEM, H. B., BIALA, K. and MORAND-FEHR, P. (Eds.). Sustainable grazing, nutritional utilization and quality of sheep and goat products. Options Méditerranéennes, Série A. Séminaires Méditerranéens, No. 67. Zaragoza: CIHEAM.

LORD, J. M. 1990. The maintenance of Poa cita grassland by grazing. New Zealand Journal of Ecology, 13(1): 43-49.

MERUNKOVÁ, K. and CHYTRÝ, M. 2012. Environmental control of species richness and composition in upland grasslands of the southern Czech Republic. Plant Ecology, 213(4): 591-602.

MLÁDEK, J. 2005. Pastva jako prostředek údržby trvalých travních porostů v CHKO. Závěrečná zpráva projektu VaV/620/11/03. ZO ČSOP 58/06 Bílé Karpaty.

MLÁDEK, J. 2008. Impact of grazing on species diversity [in Czech: Vliv pastvy na druhovou diverzitu]. In: JONGEPIEROVÁ, I. (Ed.). Louky Bílých Karpat. Veselí nad Moravou: ZO ČsOP Bílé Karpaty.

MLÁDEK, J., PAVLÜ, V., HEJCMAN, M. and GAISLER, J. 2006. Pastva jako prostředek údržby trvalých travních porostů v chráněných územích. Praha: VÚRV, v.v.i.

MORAVEC, J., BLAŽKOVÁ, D., HEJNÝ, S. et al. 1994. Fytocenologie. $1^{\text {st }}$ Edition. Praha: Academia,

NĚMEČEK, J. et al. 2011. Taxonomický klasifikační systém půd České republiky. $2^{\text {nd }}$ Editon. Praha: ČZU v Praze.

PARTZSCH, M. 2000. Die Porphyrkuppenlandschaft des unteren Saaletals - Strukturwandel ihrer Vegetation in den letzten vier Jahrzehnten. Tuexenia, 20: 153-187.

PAVLŮ, V., HEJCMAN, M., PAVLÜ, L. and GAISLER, J. 2007. Restoration of grazing management and its effect on vegetation in an upland grassland. Applied Vegetation Science, 10(3): 375-382.

PELIŠEK, J. 1939. Půdy stepní oblasti u Mohelna a stručná charakteristika půd západomoravských. In: Archiv Svazu pro ochranu prírody a domoviny v zemi Moravskoslezské-Mohelno. Vol. II. $1^{\text {st }}$ Edition. Brno: Svaz pro ochranu přírody a domoviny v zemi Moravskoslezské, $128 \mathrm{~s}$.

PELÍŠEK, J. 1948. Půdoznalecká exkurse na stepní oblast u Mohelna. Př́roda, 41(4): 73-76.

PIRO, Z. and WOLFOVÁ, J. 2008. Zachování biodiverzity karpatských luk. Praha: FOA, Nadační fond pro ekologické zemědělství.

PRÉVOSTO, B., KUITERS, L., BERNHARDT-RÖMERMANN, M., DÖLLE, M., SCHMIDT, W., HOFFMANN, M., VAN UYTVANCK, J., BOHNER, A., KREINER, D., STADLER, J., KLOTZ, S. and BRANDL, R. 2011. Impacts of land abandonment on vegetation: successional pathways in European habitats. Folia Geobotanica, 46(4): 303-325.

SPATZ, G., PAPACHRISTOU, T. G., PAPANASTASIS, V. P., FRAME, J. and NASTIS, A. S. 1999. Ecological strategies of shrubs invading extensified grasslands: their control and use. In: Grasslands and woody plants in Europe. Proceedings of the International occasional symposium of the European Grassland Federation, 27-29 May 1999. Thessaloniki, Greece, pp. 27-36.

ŠTÝBNAROVÁ, M. and MIČOVÁ, P. 2014. Floristické složení travinné vegetace v okolí turistické chaty Švýcárna při obnovené pastvě skotu - odborné sdělení. Výzkum v chovu skotu, 204(2): 21-37.

TASSER, E. and TAPPEINER, U. 2002. Impact of land use changes on mountain vegetation. Applied Vegetation Science, 5: 173-184.

TER BRAAK, C. J. F. and ŠMILAUER, P. 2002. Canoco for Windows 4.5. Wageningen: Centre for Biometry Wageningen CPRO-DLO.

VESELÝ, P. 2000. Pastva v NPR Mohelenská hadcová step. Ochrana prírody, 6(5): 168-170.

VESELÝ, P. 2002. Mohelenská hadcová step historie vzniku rezervace a jejího výzkumu. $1^{\text {st }}$ Edition. Brno: MZLU v Brně.

VESELÝ, P. 2014. Pastva malých přežvýkavců v chráněných oblastech. $1^{\text {st }}$ Edition. Brno: Mendelova univerzita $v$ Brně.

VESELÝ, P. and HAVLÍČEK, Z. 2011. Metodika hodnocení managementu pastvy na chráněných biotopech. $1^{\text {st }}$ Editon. Brno: Mendelova univerzita v Brně. 
VESELÝ, P. and ŘEPKA, R. 2005. Specifikum hodnocení vegetace po pětileté pastvě ovcí na Mohelenské hadcové stepi. In: VI. Kábrtovy dietetické dny. $1^{\text {st }}$ Edition. Brno: Veterinární a farmaceutická univerzita v Brně, pp. 58-61.

VOZÁR, L. and JANČOVIČ, J. 2004. Diversity of anthropogenic impacted association Lolio-Cynosuretum Typicum R.Tx. 1937. In: Produkčné, ekologické a krajinotvornéfunkcie trávnych ekosystémov a kŕmných plodín. SPU Nitra, pp. 136-143.

WASSEN, M. J., VENTERINK, H. O., LAPSHINA, E. D. and TANNEBERGER, F. 2005. Endangered plants persist under phosphorus limitation. Nature, 437(7058): 547-550.

ZBÍRAL, J. et al. 2004. Jednotné pracovní postupy. Analýza půd III. Brno: ÚKZÚZ.

ZBÍRAL, J. et al. 2010. Jednotné pracovni postupy. Analýza půd I. Brno: ÚKZÚZ.

ZBÍRAL, J. et al. 2011. Jednotné pracovní postupy. Analýza půd II. Brno: ÚKZÚZ.

ŽÁKOVÁ, I., BÍLEK, M. and BENDOVÁ, P. 2004. Hodnocení změn floristického složení porostů zvláště chráněných území Prahy za 3 roky smíšené pastvy ovcí a koz. In: ŽIŽLAVSKÝ, J. and HRABĚ, F. (Eds.). Sborník z mezinárodni vědecké konf. Pastvina a zviře. Brno: AF MZLU, pp. 168-177.

Contact information

Marie Mrázková-Štýbnarová: marie.mrazkova@vuchs.cz 